\title{
ECOLOGICAL MATERIAL SOLUTIONS WITH USE OF COMPOSITES
}

\author{
Damian Jończyk ${ }^{\varpi}$ \\ Faculty of Civil Engineering, Czestochowa University of Technology, Częstochowa, Poland
}

\begin{abstract}
Due to the global problem related to the excessive amount of waste, measures are also taken in the construction industry to protect the environment and implement recycled waste for the production of building materials. Due to the high popularity of composite materials in construction, a brief overview of modern ecological solutions using recycling was presented. The presented solutions are divided into three groups: the use of recycled aggregates for the production of concrete, the use of recycled aggregates for structures reinforced with geo-synthetics, and the use of recycled plastic for the production of wood-plastic composites (WPCs). The division into these three groups was determined on the basis of the selection of solutions most widely discussed in scientific articles in the field of recycling. The strength of the elements was mainly analyzed. The most widely used and showing the best strength values is the solution based on the use of recycled aggregate. The use of plastic waste is possible, but requires further research.
\end{abstract}

Key words: aggregate, geosynthetics, plastic, recycling, wood

\section{INTRODUCTION}

Currently, one of the biggest global problems is the large amount of waste which is unknown. Building construction is among the many sectors which significantly affect waste management (Aly, 2012; Lila, Kumar \& Sharma, 2013). Every year, many new elements are produced, and at the same time many become waste. As an example of how much impact the construction industry has on the environment, the data presented by Moallemi Pour and Alam (2016) can be used to inform that on average $1 \mathrm{t}$ of concrete is produced annually per person in the world. In recent years, more and more attention has been paid to the concept of sustainable construction, combined with ecology, and one of its basic aspects is the use of waste materials for the production of new elements, i.e. recycling.

Materials widely used in the construction industry with good properties are various types of composites, which are increasingly used even in single-family housing (Kendall, 2007). Composites are bio-sustainable materials and less energy is usually needed to make them (Hollaway, 2003). Composite materials are constantly developed, which allows achieving better and better properties, especially when using recycled materials (Bobko \& Całusiński, 2012; Góra, 2014; Brózda, 2015; Niemiro, 2016; Adamczyk, Grzesik \& Harat, 2018).

For a long time, the solution used in construction, based on recycling, is the use of various aggregate substitutes. In addition, an important aspect at the present time is the management of plastic waste. Therefore, the information presented in the article focuses on two thematic scopes: recycled aggregates, both as a replacement for concrete aggregates and as a replacement for road pavement layers, and the use of plastic in the production of construction structural elements. The purpose of this article is a briefly review of the latest trends in the use of recycled materials for the 
production of various types of composite materials. The presented solutions are divided into three groups: the use of recycled aggregates for the production of concrete, the use of recycled aggregates for structures reinforced with geo-synthetics, and the use of recycled plastic for the production of wood-plastic composites (WPCs). The presented division was adopted on the basis of the analysis of the most popular design solutions discussed in scientific articles in the field of recycling. While discussing each type of structural solution, the author believes that the most interesting proposals are presented. The analysis of the presented literature focuses on the strength properties of elements made with the addition of recycled materials.

\section{THE USE OF RECYCLED AGGREGATES}

The solution used in the building construction for a long time consists in an application of various construction waste as aggregate for the production of concrete. In the case of steel-concrete composite structures, the solution allowing recycling consists in making a concrete mix to fill the steel pipe using waste aggregates. Structures of this type are designated by the recycled aggregate concrete filled steel tube (RACFST). Despite a decrease in the element rigidity by $0.1-9.2 \%$ (Wang, Chen \& Geng, 2015), the use of recycled aggregate is a beneficial alternative to natural aggregates allowing the use of waste. The beneficial fact is the same nature of destruction of samples with concrete based on natural aggregate and on recycled aggregate (Wang et al., 2015).

When using a concrete mix based on recycled aggregate, an important issue is the adhesion of concrete

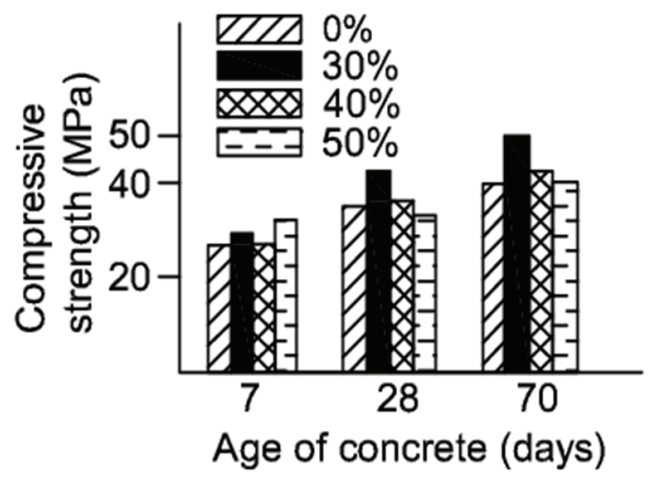

to the used reinforcement. Moallemi Pour and Alam (2016) present adhesion tests of concrete based on recycled aggregate, added in various proportions (30, 40 and $50 \%$ ) to the concrete mix. The results were compared with samples made using only natural aggregate. The adhesion for both types of aggregates showed similar characteristics. The best results for both compressive strength of concrete (Fig. 1) and adhesion were demonstrated by samples with the addition of $30 \%$ recycled aggregate. Samples with the addition of $50 \%$ recycled aggregate achieved the most similar properties to traditional concrete.

Fraj and Idir (2017) studied the impact of the type of waste aggregate used on concrete properties. They used three types of aggregate for testing: the lowest class of road waste, ordinary concrete from demolished buildings and high-grade concrete. The control series were samples of concrete based on natural aggregate. Samples using aggregate made of high-grade recycled concrete showed the best physical properties and higher compressive strength, however, they were also characterized by higher porosity (six times higher water absorption compared to samples based on natural aggregate). However, the authors emphasize the importance of using recycled aggregates due to the lack of the need to of transport of natural aggregates over very long distances.

A comprehensive review of a research on the use of recycled aggregate in pipe columns made of composite material - fibre-reinforced plastic (FRP) - filled with concrete, was done by $\mathrm{Xu}$, Chen, Xiao, Demartino and Wang (2017). Based on the analysis of previous research, it was found that the use of aggregate from waste has a positive effect on the properties of con-

Fig. 1. Compressive strength values for various additions of recycled aggregate, measured after 7, 28 and 70 days after execution (based on: Moallemi Pour \& Alam, 2016) 
crete, but the increase in strength is slower than when using natural aggregate. An important note regarding the use of waste aggregate is the information that the use of soaked waste aggregate degrades the value of concrete strength. Only the addition of dry aggregate is beneficial.

Due to the frequency of earthquakes, research is also being carried out on the use of waste aggregate for making structural elements used in seismically active areas. In the study by Marthong et al. (2017) the strength of the beam-column joint was examined. The best test results were obtained when 30\% recycled aggregate was used. In addition, attention was drawn to the fact that during seismic tests in elements made of recycled aggregate, degradation of stiffness was slower. In Polish conditions, this type of constructions may be used in mining areas.

Most scientific articles indicate a positive aspect of the use of recycled aggregate, while in the work by Younis, Ebead and Judd (2018), which analyzed the impact of waste aggregate use on long-term maintenance costs, its positive impact was not demonstrated.
A relatively new but more widely studied solution is the use of plastic waste as aggregate for mortars and concretes. According to Badache, Benosman, Senhadji and Mouli (2018), the annual production of plastic in the world is over 300 million $t$, and thus the annual amount of plastic waste is over 25 million t. A large amount of waste necessitates better management. One way is to use high-density plastic from HDPE polyethylene pipes as a replacement for fine aggregate for mortars. Figure 2 presents a graph of HDPE aggregate grain size. Preliminary studies showed a $38 \%$ increase in mortar strength when 60\% HDPE was added (Badache et al., 2018).

A wider use of plastic waste is presented by JacobVaillancourt and Sorelli (2018). Various post-consumer packaging, properly sorted, was used for the tests (Fig. 3). The best results were obtained using 20\% $\mathrm{PVC}$ as a substitute for fine aggregate. Samples with the above amount of plastic aggregate showed a decrease in thermal conductivity compared to samples on natural aggregate. Long-term mechanical properties were comparable to those on natural aggregate.

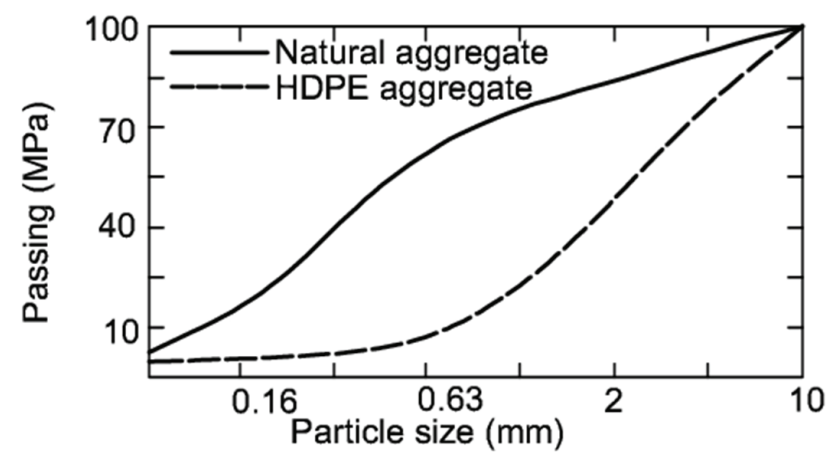

Fig. 2. Aggregate grain based on polyethylene pipes and natural aggregate (based on: Badache et al., 2018)

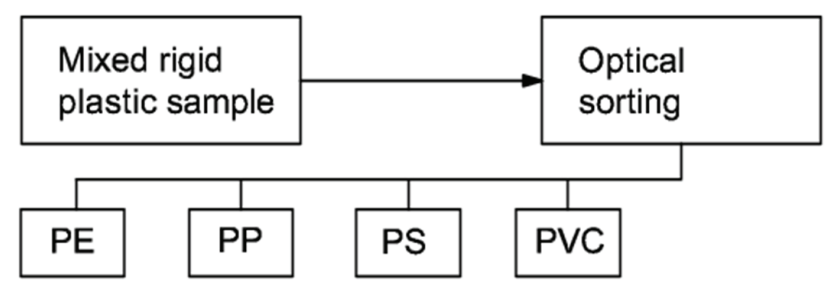

Fig. 3. Diagram of possible waste segregation used for making composite elements (based on: Jacob-Vaillancourt \& Sorelli, 2018) 


\section{WOOD-PLASTIC COMPOSITES}

Another group of new solutions using recycled materials is the use of plastic waste for the production of WPCs. In order to reduce the scale of tree felling and the use of excessive amounts of plastic waste, a combination of two materials was proposed: plastic as a matrix and wood fibers as reinforcement, forming a composite material. In addition to the above-mentioned composite, various materials are used as fillers.

Väntsi and Kärki (2014) proposed 20, 30 and 40\% mineral wool as a WPC filler. The addition of mineral wool reduced the bending strength as the amount of wool used increased (Fig. 4). As a reason for the negative impact of the abovementioned filling, the authors give a poor adhesion between wool fibers and matrix and different orientation of wool fibers.

Other fillers which can be used in WPCs are nanoclay, calcium carbonate and talc. The study of the impact of these fillers on the properties of WPCs is presented by Srivabut, Ratanawilai and Hiziroglu (2018).

The research received a large scatter of results depending on:

- preliminary properties,

- manufacturing methods,

- interaction between materials.

The composite showed the best properties when using a $7 \%$ calcium carbonate filling.

The disadvantage of WPCs is the low compatibility between hydrophilic lignocellulose and hydropho-



Fig. 4. Bending strength with various addition of mineral wool as a filler for WPCs (after preliminary measurements and after cyclic loading) (based on: Väntsi \& Kärki, 2014) bic plastic (Hung, $\mathrm{Wu}, \mathrm{Chen} \& \mathrm{Wu}, 2016)$. A way to improve these properties, according to the authors of this publication, is the use of acetylation. This process improves elasticity, tensile strength and reduces composite creep.

Due to the need of recycling of a very large amount of plastic, research is also underway to produce components that do not differ in properties from WPCs, but only made of plastic without addition of wood. Herrera, Bedoya-Ruiz and Hurtado (2018) present seismic tests of walls built of boards made of plastic waste, but the authors point out the need for further research on this solution.

\section{RECYCLED MATERIALS AND GEOSYNTHETICS}

Geosynthetics favorably affect the static work of reinforced elements with their use, so it is reasonable in this case to try using recycled materials to create a composite with the required properties and in addition being an ecological product. The most popular solution is the use of geosynthetics to strengthen and stabilize recycled aggregates. The use of various types of geosynthetics (geogrids, geotextiles, geocells) improves the properties of elements with waste aggregate by reducing deformation and stress (Han \& Thakur, 2014). In addition, in some cases smaller deformations can be achieved using recycled aggregate (Fig. 5). The above solutions are currently the subject of research because research shows that the use of recycled aggregates

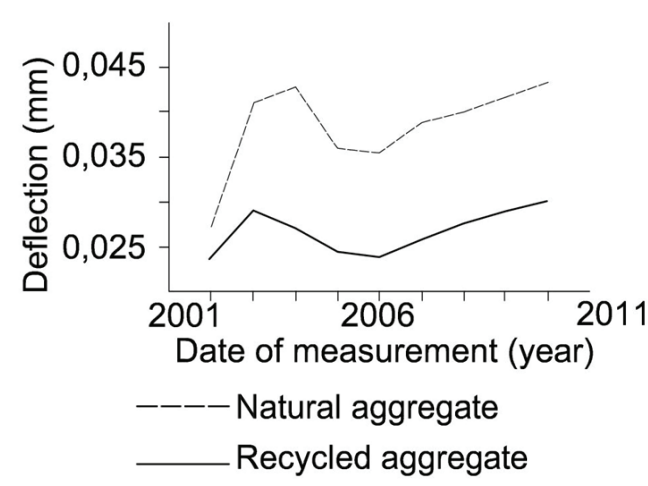

Fig. 5. Average deformation of surfaces reinforced with geosynthetics with natural and recycled aggregate (based on: Han \& Thakur, 2014) 
does not significantly adversely affect the properties of the used geosynthetics (Vieira \& Pereira, 2015).

Another way of using geosynthetics which positively affects short-term and long-term deformation values is to strengthen the asphalt mix prepared using recycled materials (Han \& Thakur, 2014; Hegde, 2017).

In the case when the asphalt mix is the recycled aggregate, the solution showing beneficial properties consists in combination of the geocell with recycled aggregate. In this case, one obtains a foundation which can be used even on weak ground (Thakur, Han, Pokharel \& Parsons, 2012). The most effective use of recycled aggregate as a replacement for concrete aggregate can be achieved by adding an average of $35 \%$ of waste. Such an amount of recycled aggregate allows to maintain the strength properties as for concrete from natural aggregate, and in some cases even better (Moallemi Pour \& Alam, 2016). However, there are problems with the effect of moisture when using recycled aggregate. The water absorption can be much worse and the use of wet aggregate can reduce the mechanical properties of the concrete.

Research on the use of plastic as a matrix substitute in composites shows different values. Some studies have shown a decrease in mechanical properties. However, the authors presenting the results also presented the proposed ways to improve the properties.

\section{CONCLUSIONS}

The article presents a brief overview of current research trends in the use of recycled raw materials for the production of composite materials used in construction.

Due to the growing problem with garbage management, the use of waste is an important element in researching new building materials. Materials using recycled raw materials in most cases are not worse to the mechanical properties of traditional materials, and are often superior to them in this respect.

Particular attention should be paid to the possibilities of using plastic waste, as it is currently one of the most difficult waste to manage.

The presented ecological types of solutions are diverse and relate to various structural aspects in con- struction. The use of recycled aggregates in the production of concrete is a solution that has been used for a long time and has a beneficial or neutral effect on the mechanical properties of elements or materials. However, recycled materials should be used with caution, as sometimes other properties, such as water absorption, may have worse parameters. Plastic waste can be used both as a replacement for aggregate and as a component for the production of small structural elements.

\section{REFERENCES}

Adamczyk, Z., Grzesik, B. \& Harat, A. (2017). Środowiskowe skutki stosowania żużla hutniczego jako składnika kruszyw. Zeszyty Naukowe Politechniki Częstochowskiej. Budownictwo, 23, 9-15. https://doi.org/10.17512/ znb.2017.1.01

Aly, M. (2012). Development of an Eco-friendly Composite Material for Engineering Applications ( $\mathrm{PhD}$ thesis). Dublin City University, Dublin. http://doras.dcu. ie/16857/1/Marwa_Aly_Final_thesis_for_printing.pdf

Badache, A., Benosman, A. S., Senhadji, Y. \& Mouli, M. (2018). Thermo-physical and mechanical characteristics of sand-based lightweight composite mortars with recycled high-density polyethylene (HDPE). Construction and Building Materials, 163, 40-52. https://doi. org/10.1016/j.conbuildmat.2017.12.069

Bobko, T. \& Całusiński, P. (2012). Modelowanie racjonalnych powiazań pomiędzy parametrami inżynierii procesowej w produkcji energooszczędnych elementów budowlanych. Zeszyty Naukowe Politechniki Częstochowskiej. Budownictwo, 18, 13-27.

Brózda, K. (2015). Ekologiczne materiały kompozytowe w budownictwie. In M. Ulewicz, J. Selejdak (Eds.), Ekoinnowacje w materiatach i technologiach budowlanych (pp. 60-69). Częstochowa: Wydawnictwo Wydziału Zarządzania Politechniki Częstochowskiej.

Fraj, A. B. \& Idir, R. (2017). Concrete based on recycled aggregates - Recycling and environmental analysis: A case study of Paris' region. Construction and Building Materials, 157, 952-964. https://doi.org/10.1016/j.conb uildmat.2017.09.059

Góra, J. (2014). Możliwości zastosowania polskich kruszyw węglanowych do betonów wysokowartościowych. In S. Fic (Ed.), Materiaty kompozytowe $i$ możliwości ich zastosowania $w$ budownictwie tradycyjnym i energooszczędnym (pp. 21-30). Lublin: Politechnika Lubelska. 
Han, J. \& Thakur, J. K. (2014). Sustainable roadway construction using recycled aggregates with geosynthetics. Sustainable Cities and Society, 14, 342-350. https://doi. org/10.1016/j.scs.2013.11.011

Hegde, A. (2017). Geocell reinforced foundation beds-past findings, present trends and future prospects: A stateof-the-art review. Construction and Building Materials, 154, 658-674. https://doi.org/10.1016/j.conbuildmat.20 17.07.230

Herrera, J. P., Bedoya-Ruiz, D. \& Hurtado, J. E. (2018). Seismic behavior of recycled plastic lumber walls: An experimental and analytical research. Engineering Structures, 177, 566-578. https://doi.org/10.1016/ j.engstruct.2018.10.006

Hollaway, L. C. (2003). The evolution of and the way forward for advanced polymer composites in the civil infrastructure. Construction and Building Materials, 17, 365378. https://doi.org/10.1016/S0950-0618(03)00038-2

Hung, K. C., Wu, T. L., Chen, Y. L., Wu, J. H. (2016). Assessing the effect of wood acetylation on mechanical properties and extended creep behavior of wood/recycled-polypropylene composites. Construction and Building Materials, 108, 139-145. https://doi.org/10.1016/j.c onbuildmat.2016.01.039

Jacob-Vaillancourt, C. \& Sorelli, L. (2018). Characterization of concrete composites with recycled plastic aggregates from postconsumer material streams. Construction and Building Materials, 182, 561-572. https://doi. org/10.1016/j.conbuildmat.2018.06.083

Kendall, K. (2007). Building the future with FRP composites. Reinforced Plastics, 5, 26-33.

Lila, M. K., Kumar, F., Sharma, S. (2013). Composites from waste for civil engineering applications. i-manager's Journal on Material Science, 1 (3), 1-10.

Marthong, C., Sangma, A. S., Choudhury, S. A., Pyrbot, R. N., Tron, S. L., Mawroh, L. \& Bharti, G. S (2017). Structural Behavior of Recycled Aggregate Concrete Beam-Column Connection in Presence of Micro Concrete at Joint Region. Structures, 11, 243-251. https:// doi.org/10.1016/j.istruc.2017.07.001

Moallemi Pour, S. \& Alam, M. S. (2016). Investigation of Compressive Bond Behavior of Steel Rebar Embedded in Concrete With Partial Recycled Aggregate Replace- ment. Structures, 7, 153-164. https://doi.org/10.1016/ j.istruc.2016.06.010

Niemiro, J. (2016). Analiza i wykorzystanie dźwiękochłonnych właściwości granulatu gumowego pozyskanego z recyklingu. Zeszyty Naukowe Politechniki Częstochowskiej. Budownictwo, 22, 257-264. https://doi. org/10.17512/znb.2016.1.25

Srivabut, C., Ratanawilai, T. \& Hiziroglu, S. (2018). Effect of nanoclay, talcum, and calcium carbonate as filler on properties of composites manufactured from recycled polypropylene and rubberwood fiber. Construction and Building Materials, 162, 450-458. https://doi. org/10.1016/j.conbuildmat.2017.12.048

Thakur, J. K., Han, J., Pokharel, S. K. \& Parsons, R. L. (2012). Performance of geocell-reinforced recycled asphalt pavement (RAP) bases over weak subgrade under cyclic plate loading. Geotextiles and Geomembranes, 35, 14-24. https://doi.org/10.1016/j.geotexmem.2012.06.004

Väntsi, O. \& Kärki, T. (2014). Utilization of recycled mineral wool as filler in wood-polypropylene composites. Construction and Building Materials, 55, 220-226. https://doi.org/10.1016/j.conbuildmat.2014.01.050

Vieira, C. S. \& Pereira, P. M. (2015). Transportation Geotechnics Damage induced by recycled Construction and Demolition Wastes on the short-term tensile behaviour of two geosynthetics. Transportation Geotechnics, 4, 64-75. https://doi.org/10.1016/j.trgeo.2015.07.002

Wang, Y., Chen, J. \& Geng, Y. (2015). Testing and analysis of axially loaded normal-strength recycled aggregate concrete filled steel tubular stub columns. Engineering Structures, 86, 192-212. https://doi.org/10.1016/ j.engstruct.2015.01.007

Xu, J. J., Chen, Z. P., Xiao, Y., Demartino, C. \& Wang, J. H. (2017). Recycled Aggregate Concrete in FRP-confined columns: A review of experimental results. Composite Structures, 174, 277-291. https://doi.org/10.1016/ j.compstruct.2017.04.034

Younis, A., Ebead, U. \& Judd, S. (2018). Life cycle cost analysis of structural concrete using seawater, recycled concrete aggregate, and GFRP reinforcement. Construction and Building Materials, 175, 152-160. https://doi. org/10.1016/j.conbuildmat.2018.04.183 


\section{EKOLOGICZNE ROZWIAZZANIA MATERIAŁOWE Z WYKORZYSTANIEM KOMPOZYTÓW}

\section{STRESZCZENIE}

Ze względu na globalny problem związany z nadmierną ilością odpadów w branży budowlanej także podejmowane są działania na rzecz ochrony środowiska i wdrożenia do produkcji materiałów budowlanych z odpadów pochodzących z recyklingu. W związku z dużą popularnością materiałów kompozytowych w budownictwie przedstawiono krótki przegląd nowoczesnych rozwiązań ekologicznych wykorzystujących recykling. Zaprezentowane rozwiązania podzielono na trzy grupy: wykorzystanie kruszyw z recyklingu do produkcji betonu, użycie kruszyw recyklowanych do konstrukcji wzmacnianych geosyntetykami oraz użycie plastiku z recyklingu do wytwarzania kompozytów drewniano-plastikowych WPC (ang. wood-plastic composites). Podział na wspomniane trzy grupy został określony na podstawie wyboru rozwiązań najszerzej omawianych w artykułach naukowych z zakresu recyklingu. Głównie analizowano wytrzymałość elementów. Rozwiązanie z zastosowaniem kruszywa z recyklingu jest najszerzej wykorzystywane i przedstawia najlepsze wartości wytrzymałości. Użycie odpadów plastikowych jest możliwe, jednak wymaga dalszych badań.

Słowa kluczowe: kruszywo, geosyntetyki, recykling, plastik, drewno 